\section{Frost damage to eucalypts in a short- rotation forestry trial in Cumbria (England)}

\author{
Andrew D Leslie ${ }^{(1)}$, Maurizio Mencuccini ${ }^{(2)}$, Mike Perks $^{(3)}$
}

Cold is the main climatic constraint to planting eucalypts in Britain and the winter of 2009-2010, the coldest in thirty years, proved particularly challenging for their survival. Damage to transplants planted in May 2009 of two species of eucalypts, Eucalyptus gunnii and Eucalyptus nitens, were assessed over the winter of 2009/2010 at a trial in Cumbria, northern England. Larger trees were found to have exhibited less cold damage by the end of January 2010, but by May there were no significant differences in survival due to tree size. By late January, there were statistically significant differences in damage between $E$. gunnii and $E$. nitens with the former being more cold tolerant. However, damage at the end of January, after minimum temperatures of -14 ${ }^{\circ} \mathrm{C}$, did not appear serious, yet by May the survival of $E$. gunnii was $37 \%$ and for $E$. nitens was less than $1 \%$. As larger trees exhibited relatively less frost damage it is recommended that intensive silviculture be practiced to ensure trees are between 1 and $1.5 \mathrm{~m}$ tall prior to their first winter to reduce the extent of damage through frost.

Keywords: Frost, Cold, Eucalyptus, England

\section{Introduction}

Short rotation forestry (SRF) involves growing trees in plantation at a spacing that allows rapid site capture and which are then harvested at a dbh of between 10 and $20 \mathrm{~cm}$ (Hardcastle 2006). The wood produced is normally used to substitute fossil fuels as a source of energy. A number of hardwoods were identified as having potential for SRF in the UK (Hardcastle 2006), but the Read Report (Read et al. 2009) highlighted the potential of eucalypts in sequestration of atmospheric carbon, due to their rapid growth. Of these, two species were identified as having particular potential for the UK: Eucalyptus gunnii Hook.f. and Eucalyptus nitens (Deane and Maiden) Maiden (Hardcastle 2006). There are limited data on growth, but increments of between $3 \mathrm{~m}^{3} \mathrm{ha}^{-1} \mathrm{y}^{-1}$ (Kerr \& Evans 2011) and $18 \mathrm{~m}^{3} \mathrm{ha}^{-1} \mathrm{y}^{-1}$ (Cope et al. 2008) have been reported for E. gunnii at a 7 and 25 year rotation, respectively, and above 30 $\mathrm{m}^{3}$ ha $^{-1} \mathrm{y}^{-1}$ on a 8 year rotation for $E$. nitens

(Purse \& Richardson 2001).

It is cold that presents the greatest limitation to growing eucalypts in the UK (Leslie et al. 2012). Low temperatures have two main negative impacts on the photosynthesis of eucalypts. The first is damage to tissues due to rupture of cells, while the second is photoinhibition of photosynthesis (Davidson et al. 1995). Photoinhibition involves a decrease in the efficiency of photosystem II through the combination of cold temperatures and high levels of sunlight (Close \& Beadle 2003). Photoinhibition occurs least and recovery is most rapid in the most coldtolerant eucalypts (Hovenden \& Warren 1998).

Furthermore, low soil temperatures are known to decrease absorption of water by roots (Teskey et al. 1984, in Cochrane \& Slayter 1988). When the soil is frozen uptake can be seriously disrupted; generally, soil temperatures of $-1{ }^{\circ} \mathrm{C}$ or less will prevent water uptake and can increase dehydra-

(1) National School of Forestry, University of Cumbria, Penrith Campus, Newton Rigg, CA11 OAH Penrith, England (UK); (2) School of Geosciences, University of Edinburgh, Crew Building, The King's Buildings, West Mains Road, EH9 3JN Edinburgh, Scotland (UK); (3) Centre for Forestry and Climate Change, Forest Research Northern Research Station, EH25 9SY Roslin Midlothian, Scotland (UK)

@ Andrew D Leslie (andrew.leslie@cumbria.ac.uk)

Received: Oct 22, 2013 - Accepted: Jan 13, 2014

Citation: Leslie AD, Mencuccini M, Perks M, 2014. Frost damage to eucalypts in a shortrotation forestry trial in Cumbria (England). iForest 7: 156-161 [online 2014-01-23] URL: http://www.sisef.it/iforest/contents/?id=ifor1161-007

Communicated by: Marco Borghetti tion (Larcher 1957, in Boyce \& Lucero 1994). During periods of warm air temperatures with frozen ground, trees must rely on moisture stored in sap reserves and smaller trees will deplete these reserves faster (Boyce \& Lucero 1994).

Eucalypts have four main ways of producing leafy shoots; naked buds in leaf axils, accessory buds, dormant (epicormic) buds and buds in lignotubers. The latter two, dormant and lignotuber buds are particularly important in producing shoots after significant damage, such as fire or frost. However, it is the naked buds and accessory buds that normally contribute to crown development. The naked buds primarily contribute to the development of leafy shoots, with accessory buds providing an alternative if the naked buds are damaged (Jacobs 1955, in Commonwealth Government of Australia 1999). The naked buds grow when temperatures are above a certain minimum, enabling potentially high productivity, especially when grown as exotics (Beadle et al. 1995) as this strategy allows growth through much of the year. Unlike most temperate trees, photoperiod has no effect on growth (Paton 1983). Davidson et al. (1995) note that maximum winter growth rates for E. nitens (Deane and Maiden) Maiden in a plantation in Tasmania were only slightly less than maximum rates in summer. However, this lack of dormancy also leaves eucalypts vulnerable to damage through chilling (Davidson et al. 1995). The cold winters experienced in the UK, relative to those of Australia, means that only a limited range of species (those that are from subalpine areas of Australia) have survived.

Hardening is a process crucial to providing resistance to cold and also speeds up the recovery time of photsosynthesis, following a period of cold (Davidson et al. 1995). In eucalypts a progressive decline in temperature enables hardening within just a few days (Pryor 1976, Paton 1983). Harwood (1980, in King \& Ball 1998) describes the importance of hardening, noting that there is little difference in frost resistance between subalpine species of eucalypts when they are in an unhardened state, yet when hardened they exhibit considerable variation. In sub-alpine eucalypts hardening is initiated through low temperatures, rather than reduced photoperiod (Eldridge 1969, in Almeira et al. 1994); the crucial temperature for initiating hardening being between $2{ }^{\circ} \mathrm{C}$ (Paton 1983) and 4 ${ }^{\circ} \mathrm{C}$ (Davidson \& Reid 1987). However, both the level and duration of cold is important to the hardening process and it is a characteristic only of those eucalypts from colder climates (Scarascia-Mugnozza et al. 1989).

Hardening does not seem to increase markedly the ability of cold-tolerant eucalypts to limit damage through tolerating supercooling of their tissues, rather it seems to confer re- 
sistance to cold through other means (Scarascia-Mugnozza et al. 1989). The mechanism involves an increase in concentration of soluble sugars, stabilising cell membranes and possibly also providing photosynthetic precursors enabling more efficient winter photosynthesis (Almeira et al. 1994). Another chemical associated with cold hardiness is anthocyanin, a pigment which is thought to act through reducing absorption of light during photoinhibition and also possibly through a role of quenching antioxidants (Close et al. 2004). In frost resistant eucalypts, damage occurs at temperatures well below that which ice forms in the tissues, and so death of cells appears to be related to dehydration (Olien 1978, in Valentini et al. 1990, Steponkus 1984, in Valentini et al. 1990). As the water potential of ice is lower than liquid water, freezing draws water from the cells and causes them to dehydrate. If this loss of water is sufficient it can cause disruption to cell membranes resulting in leakage (Pearce 2001). This injury, caused by frost dehydration occurs in hardened individuals at a lower temperature than unhardened ones (Valentini et al. 1990) and so unseasonal cold is particularly damaging. In a comparison of eucalypt species, the cold-resistant $E$. gunnii was found to respond rapidly to lower temperatures enabling it to cope with the development of extracellular ice and the associated dehydration of tissues. ScarasciaMugnozza et al. (1989) and Valentini et al (1990) also noted that the capacity of cold tolerant eucalypts to retain intracellular water was considerably increased by cold hardening.

Recent work undertaken in Ireland has focused on two important aspects of cold tolerance in eight species of eucalypt: lethal temperature and the pattern of hardening (Black, unpublished data). Investigation of LT50 (lethal temperature for $50 \%$ of the shoots) showed considerable variation between species. Results also showed that the ranking of species in terms of those most cold tolerant differed between winter 2010 2011 and winter 2011-2012. These differences were probably due to different patterns of hardening in the two winters, the earlier winter being colder than the later one. Further investigation showed that the rate of hardening varied between eucalypt species Black (unpublished data) suggests that when selecting species, LT50 and the rate of hardening should be combined to create a measure of cold tolerance.

A polar air mass moving from continental Europe brought bitterly cold conditions to Great Britain during December 2009 and January 2010, resulting in the coldest winter in England for over thirty years (Met Office 2010), specifically since 1978/1979 (Met Office 2011a). Across the UK, the mean temperature was $2{ }^{\circ} \mathrm{C}$ below the $1971-2000$ average, with the most severe cold being in the north of the country. For northern Scotland it was the coldest winter on record and for England the ninth coldest since 1910. For northern England the lowest recorded temperature was $-17.6{ }^{\circ} \mathrm{C}$ on 7 January 2010 at Woodford, near Manchester. This was the lowest temperature for that location on record (Prior \& Kendon 2011).

The objectives of this study were to examine whether there were significant differences in frost damage and survival between $E$. gunnii and E. nitens and between larger and smaller trees over the extreme winter period of 2009/2010.

\section{Methods}

The methods section is divided in three parts, the first describing the characteristics of the trial, the second the approach used to collect data and the third the methods used to analyse frost damage and survival.

\section{Description of the trial}

A trial adopting a randomised completeblock design was established close to the Newton Rigg Campus of the University of Cumbria $\left(54^{\circ} 40^{\prime} 56^{\prime \prime} \mathrm{N}, 2^{\circ} 47^{\prime} 22^{\prime \prime} \mathrm{W}\right)$, testing five tree species in six replicates. The species used had been identified in Hardcastle (2006) as being hardwoods with sufficiently rapid growth to be used in SRF, to produce biomass for energy. These comprised, sycamore (Acer pseudoplatanus L.), alder (Alnus glutinosa L.), ash (Fraxinus excelsior L.) and two eucalypts; Eucalyptus gunnii and Eucalyptus nitens. Container-grown seedlings were planted using a " $T$ " notch and established in $60 \mathrm{~cm}$ tubes. The area was stock-fenced. Native and naturalised species were planted in November 2008, while the eucalypts were planted later, in late April 2009, with the aim of avoiding late spring frosts.

The trial was originally under grass pasture and the soil was a clay loam brown earth and slightly acid $(\mathrm{pH} 6)$. Bulk density was 0.76 at $0 \mathrm{~cm}$ to $15 \mathrm{~cm}$ depth and 1.07 at $15 \mathrm{~cm}$ to $30 \mathrm{~cm}$ depth. Soil nitrogen was 5.45 tonnes $\mathrm{ha}^{-1}$ and 4.35 tonnes ha ${ }^{-1}$ at $0 \mathrm{~cm}$ to $15 \mathrm{~cm}$ and $15 \mathrm{~cm}$ to $30 \mathrm{~cm}$ depth respectively (Centre for Ecology and Hydrology 2013). A complete-weeding approach was adopted to kill the pasture grasses using a combination of propazymide and glyphosate. Survival of trees in November, at the end of the first growing season, was over $87 \%$ for all species, E. gunnii having $87 \%$ and E. nitens having $96 \%$ survival. Growth was rapid, $E$. nitens attaining a mean height of $1.09 \mathrm{~m}$ and E. gunnii of $1.39 \mathrm{~m}$, a reflection of a rigorous complete weeding regime and an unusually wet and warm summer (Met Office 2011b). However this rapid growth led to instability in some of the larger trees, reflecting an inbalance between root development and shoot growth.

The origin of the eucalypts was given as $E$. nitens "Central Victoria" and of E. gunnii as being Region 94, which is Australia (Watson, pers. comm.). The E. gunnii supplied contained hybrids of E. gunnii and E. nitens and the foliage of the E. gunnii was not glaucous. In the opinion of Purse (pers. comm) because of these two factors, the seed was probably from the only commercial source of E. gunnii, a stand in Dipton, New Zealand. Purse (pers. comm.) also attributed the $E$. nitens to being central Victoria origin but Dipton, New Zealand provenance.

\section{Methods for data collection}

The trial at Newton Rigg followed a randomised complete block design with six replicates and plots containing 80 trees each. For this survey a sub-plot of 24 trees was created in each of these plots. All 24 trees within this sub-plot were scored on an eleven point system for frost damage on the 31 January 2010 , and then again on the 1 May 2010. The system for scoring frost damage was based on one used by Evans (1986), except that three parts of the trees were scored separately: the lower stem (within the tree shelters), the upper stem (outside the tree shelters), and the foliage, whereas Evans (1986) scored crown foliage only. The scoring ranges from 0 , which is no visible damage, to 10 which represents $91-100 \%$ damage. As a measure of necrosis, the extent to which the cambium had been blackened and the extent of discolouration of the foliage (from healthy green to damaged khaki) was used.

The trial was originally established to test yield of potential SRF species and so maintaining the plots at full stocking was important. In April 2010 the trial was beaten-up and as it was not clear whether the trees would recover, the decision was made to beat up half of the trees in the plots. As such, the size of the initial frost damage plots was reduced from 24 to 12 trees as the other half of the plot had been replaced with new trees. For E. nitens it was clear the trees would not recover and so all trees were replaced. For E. gunnii, $37 \%$ of the original trees were alive and these were not replaced.

The climatic records for the winter of 2009/2010 were obtained from the weather station $1 \mathrm{~km}$ away at the Newton Rigg Campus of the University of Cumbria. Fig. 1 shows the daily minimum and maximum air temperatures over the period between November 2009 and March 2010 at Newton Rigg Campus. In addition to the extreme cold, the daily range in temperature was considerable, reaching $20^{\circ} \mathrm{C}$ during one twenty four hour period, varying from -14 to $6{ }^{\circ} \mathrm{C}$. Twenty four hour temperature fluctuations of nearly $10{ }^{\circ} \mathrm{C}$ were frequent during the winter, due to the combination of cold nights 
and clear sunny days. During December, January, February and March, the grass minimum temperature fell below freezing on 24 , $28,25,21$ and 14 days respectively. On the 9 January 2010 the grass minimum dropped to a low of $-17{ }^{\circ} \mathrm{C}$. The period of sunshine was generally above the 1971-2000 average (Met Office 2011a). During the period between mid December and mid January there was almost constant snow cover, with depths of up to $19 \mathrm{~cm}$. During the remainder of the winter there were only infrequent, small falls of snow, the ground being bare for much of the time.

\section{Analysis of data}

The distribution of frost damage score data for cold damage at lower stem, upper stem and foliage by species was tested for normality before and after arcsine transformation. Significant departure from normal distribution was found $(p<0.0001)$, so a non parametric Kolmogorov-Smirnoff test was used to test for differences in the frost damage scores between the two species.

The role of tree size on cold damage was investigated by dividing the trees into quartiles by their height in January 2010. For these quartiles, the data on cold damage and survival was tested for conformance to a normal distribution. By quartile and by block scores for cold damage and arcsine cold damage for $E$. gunnii and for $E$. nitens were found to be significantly different from nor$\mathrm{mal}$; therefore non-parametric Kruskal-Wallis tests and Mann-Whitney U tests were applied to the data.

A Chi-squared test was used to determine whether significant differences exist in survival between the two eucalypts, between the quartiles by height and between blocks.

\section{Results}

The pattern of frost damage noted on 31 January 2010 in the lower stem, upper stem and the foliage was compared between $E$. gunnii and E. nitens using a KolmogorovSmirnoff test, finding significant differences $(\mathrm{P}<0.001)$ between the two species. E. nitens was found to be more susceptible to damage by frost to stem and foliage, as proved from higher scores for frost damage. Despite very low temperatures in January of $-14{ }^{\circ} \mathrm{C}$ minimum air temperature or $-17^{\circ} \mathrm{C}$ grass minimum, the E. gunnii showed relatively little visible damage (Fig. 2), whereas the damage to $E$. nitens was very obvious, particularly to its foliage (Fig. 3). In January, survival remained high with that of E. gunnii being $93 \%$ and of $E$. nitens being $93 \%$. The results of the assessment of 1 May 2010 showed that there had been a substantial increase in damage, particularly to foliage of both species and considerable further mortality. Survival of E. gunnii had declined to $35 \%$, whereas for E. nitens it had dropped to less

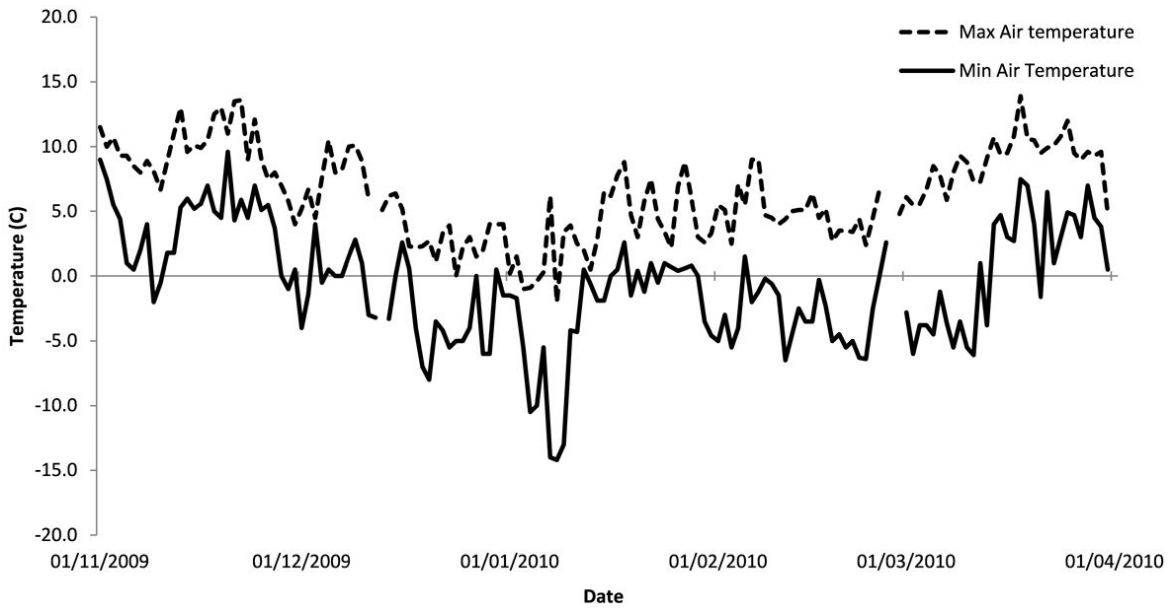

Fig. 1 - Maximum and minimum air temperatures over the winter of 2009/2010 using data from the Newton Rigg weather station.

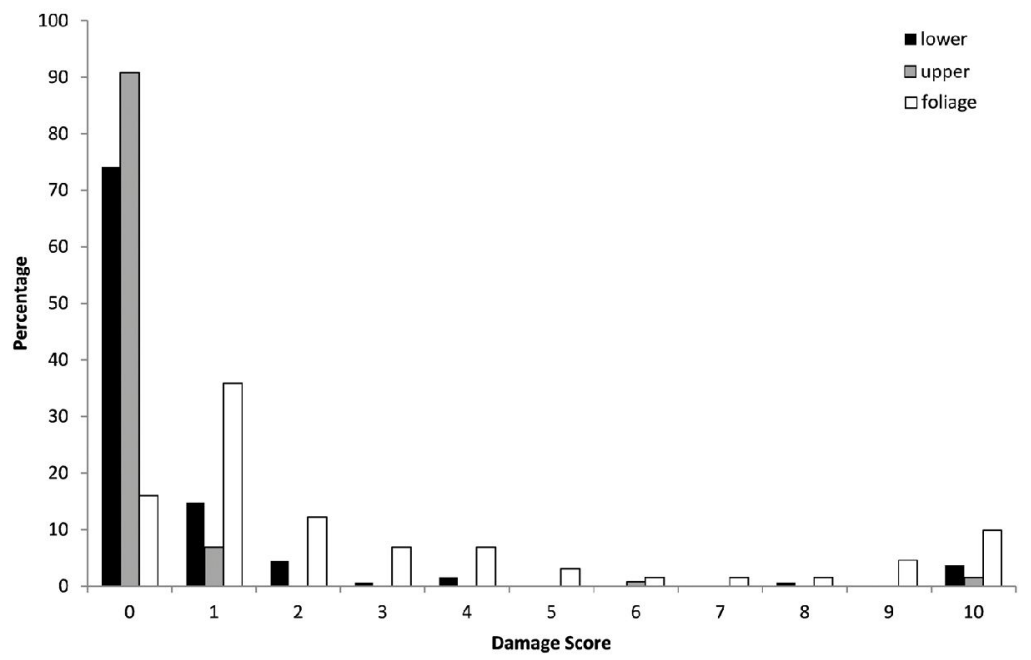

Fig. 2 - Frost damage in upper stem, lower stem and foliage of E. gunnii. (0): no damage; (1): $1-10 \%$ damage; (2): $11-20 \%$ damage; (3): $21-30 \%$ damage; (4): $31-40 \%$ damage; (5): 41-50\% damage; (6): $51-60 \%$ damage; (7): $61-70 \%$ damage; (8): $71-80 \%$ damage; (9): 81 90\% damage; (10): $91-100 \%$ damage.

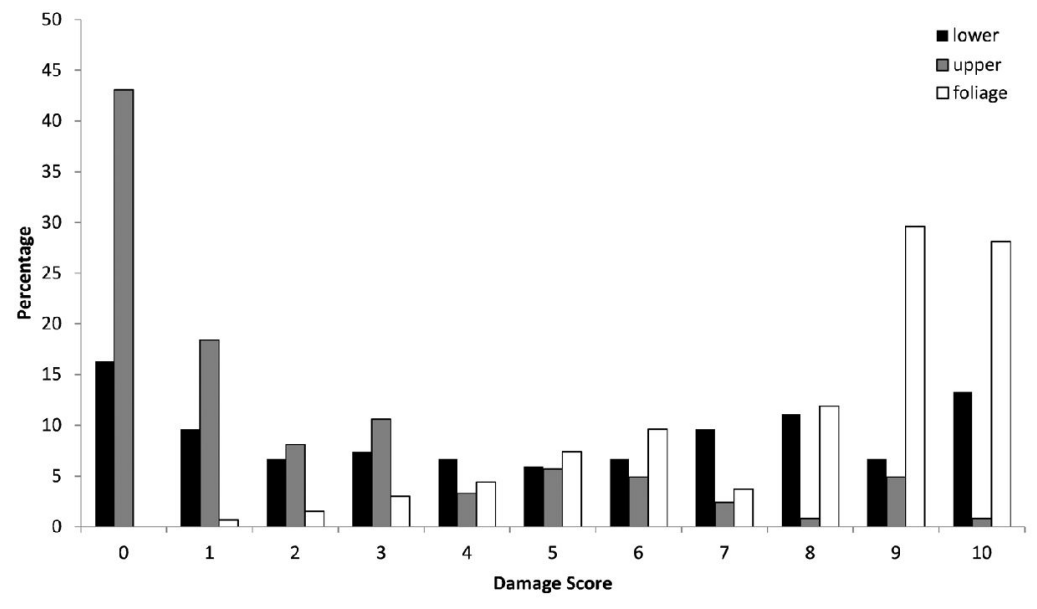

Fig. 3 - Frost damage in upper stem, lower stem and foliage of E. nitens. (0): no damage; (1): 1-10\% damage; (2): 11-20\% damage; (3): $21-30 \%$ damage; (4): $31-40 \%$ damage; (5): $41-$ 50\% damage; (6): 51-60\% damage; (7): 61-70\% damage; (8): $71-80 \%$ damage; (9): $81-90 \%$ damage; (10): $91-100 \%$ damage. 
Tab. 1 - Ranking of damage score in January 2010 by tree height, divided into quartiles, where (1): lowest damage to (4): highest damage.

\begin{tabular}{|c|c|c|c|c|c|c|c|c|}
\hline \multirow{3}{*}{$\begin{array}{l}\text { Height } \\
\text { of trees } \\
\text { by } \\
\text { Quartile }\end{array}$} & \multicolumn{4}{|c|}{ E. gunnii } & \multicolumn{4}{|c|}{ E. nitens } \\
\hline & \multirow{2}{*}{$\begin{array}{c}\text { Median } \\
\text { height } \\
\text { (cm) }\end{array}$} & \multicolumn{3}{|c|}{ Damage Score } & \multirow{2}{*}{$\begin{array}{c}\text { Median } \\
\text { height } \\
\text { (cm) }\end{array}$} & \multicolumn{3}{|c|}{ Damage score } \\
\hline & & $\begin{array}{c}\text { Lower } \\
\text { stem }\end{array}$ & $\begin{array}{c}\text { Upper } \\
\text { stem }\end{array}$ & Foliage & & $\begin{array}{c}\text { Lower } \\
\text { stem }\end{array}$ & $\begin{array}{l}\text { Upper } \\
\text { stem }\end{array}$ & Foliage \\
\hline Smallest & 98 & 3 & 4 & 4 & 73 & 4 & 4 & 4 \\
\hline Small & 131 & 4 & 3 & 3 & 108 & 2 & 2 & 2 \\
\hline Large & 155 & 1 & 2 & 2 & 122 & 3 & 1 & 3 \\
\hline Largest & 175 & 2 & 1 & 1 & 147 & 1 & 3 & 1 \\
\hline
\end{tabular}

than $1 \%$

There appeared to be a relationship between tree height and damage. The median heights for each quartile are shown in Tab. 1 with the overall ranking of damage by quartile. In E. gunnii damage to lower stem, upper stem and foliage was greatest in the quartiles containing the smaller trees. A Kruskal-Wallis test was used to examine differences in damage between quartiles. There were significant differences between quartiles for damage in the lower stem $(\mathrm{p}=0.023)$, upper stem $(p=0.025)$ and foliage $(p=0.011)$. Mann-Whitney $U$ tests were used to identify where these differences originated. These are described in Tab. 2 and the damage to the upper stem and foliage for the quartile with the smallest trees was significantly different from the other quartiles. There were other significantly significant differences but the

pattern was not clear (Tab. 2).

For E. gunnii an examination was undertaken to determine whether survival in May 2010 after months of freezing conditions was related to tree height. While survival was lowest $(30 \%)$ in the quartile containing the largest trees it was next lowest in the smallest trees $(32 \%)$ and highest survival was in the trees in the second smallest quartile (41\%). A Chi-squared test indicated that differences between survival in the quartiles were not significant $(\mathrm{p}=0.802)$.

As with $E$. gunnii, the E. nitens trees were divided into quartiles by height in January 2010 and a Kruskall-Wallis test was used to identify if the differences in frost damage by quartile were significant. Differences between quartiles in terms of foliage and lower stem damage were highly significant $(\mathrm{p}<0.0001)$. Mann Whitney tests were ap-

Tab. 2 - Probabilities from Mann-Whitney U tests comparing damage in E. gunnii between quartiles of tree height. (SL): stem low; (SH): stem high; (FO): Foliage.

\begin{tabular}{|c|c|c|c|c|}
\hline \multirow{2}{*}{\multicolumn{2}{|c|}{ Prob }} & \multicolumn{3}{|c|}{ Quartile } \\
\hline & & Small & Large & Largest \\
\hline \multirow{9}{*}{ Quartile } & \multirow{3}{*}{ Smallest } & SL: 0.960 & SL: 0.012 & SL: 0.313 \\
\hline & & SH: 0.046 & SH: 0.042 & SH: 0.022 \\
\hline & & FO: 0.041 & FO: 0.014 & FO: 0.002 \\
\hline & \multirow{3}{*}{ Small } & - & SL: 0.003 & SL: 0.153 \\
\hline & & & SH: 0.976 & SH: 0.613 \\
\hline & & & FO: 0.578 & FO: 0.194 \\
\hline & \multirow{3}{*}{ Large } & - & - & SL: 0.075 \\
\hline & & & & SH: 0.631 \\
\hline & & & & FO: 0.501 \\
\hline
\end{tabular}

Tab. 3 - Probabilities from Mann-Whitney U tests comparing lower stem damage and foliage damage in $E$. nitens between quartiles of tree height.

\begin{tabular}{|c|c|c|c|c|}
\hline \multirow{2}{*}{\multicolumn{2}{|c|}{ Prob }} & \multicolumn{3}{|c|}{ Quartile } \\
\hline & & Small & Large & Largest \\
\hline \multirow{6}{*}{ Quartile } & \multirow{2}{*}{ Smallest } & SL: 0.0001 & SL: 0.001 & SL: 0.0001 \\
\hline & & FO: 0.0001 & FO: 0.0001 & FO: 0.0001 \\
\hline & \multirow{2}{*}{ Small } & - & SL: 0.878 & SL: 0.878 \\
\hline & & & FO: 0.586 & FO: 0.586 \\
\hline & \multirow{2}{*}{ Large } & - & - & SL: 0.241 \\
\hline & & & & FO: 0.169 \\
\hline
\end{tabular}

plied to the foliage and lower stem data by quartile to identify where these differences lay and only the smallest quartile showed damage significantly different to others (Tab. $3)$.

A Kruskal-Wallis test showed that differences in damage in January between blocks for E. gunnii were not significant for lower stem and foliage, but were highly significant for upper stem. The level of upper stem damage was however low in all blocks. A similar analysis of damage in E. nitens in January and E. gunnii in May showed no significant differences in damage in lower stem, upper stem and foliage by block. There were insufficient $E$. nitens surviving in May to conduct an analysis of damage by block.

Survival of $E$. gunnii by block by May varied from $54 \%$ to $20 \%$ and a Chi-squared test showed the differences not to be significant $(\mathrm{p}=0.116)$. Despite evidence of epicormic growth in trees that were left when part of the plots were replanted, none of those that were recorded as being dead recovered during the summer. There were insufficient trees surviving of E. nitens in May to undertake a similar analysis of survival between January and May by quartile or by block.

\section{Discussion}

The influences determining the degree of damage to eucalypts from cold are complex and are related to a number of factors which are summarised in Fig. 4. However welladapted temperate eucalypts are to the UK climate, the winter of $2009 / 2010$ was the coldest in the last thirty years (Met Office 2010) and the combination of severe cold and almost three months of days where temperatures dropped below freezing will have caused severe plant stress. Further, due to clear skies, the range in temperature over 24hour periods was considerable, resulting in variation in temperature of $20^{\circ} \mathrm{C}$ during one twenty four hour period in January, during which the trees would have experienced periods of freezing and thawing of above ground and below ground tissues. Two factors may have reduced damage somewhat: the gradual but steady decline in temperatures during December (Fig. 1) would have allowed the trees to harden and also damage may have been mitigated to a degree by the insulating layer of snow that lay on the ground from mid December to mid January, protecting the roots from the extreme air temperatures.

The two species of eucalypt tested in the trial have different climatic tolerances, including their capacity to resist cold (Booth \& Pryor 1991). It is E. gunnii that inhabits a colder alpine environment in Tasmania, compared with the montane, lower latitude areas occupied by $E$. nitens on the main portion of Australia. E. gunnii is noted as being 
Fig. 4 - Summary of external and internal physiological factors affecting frost damage

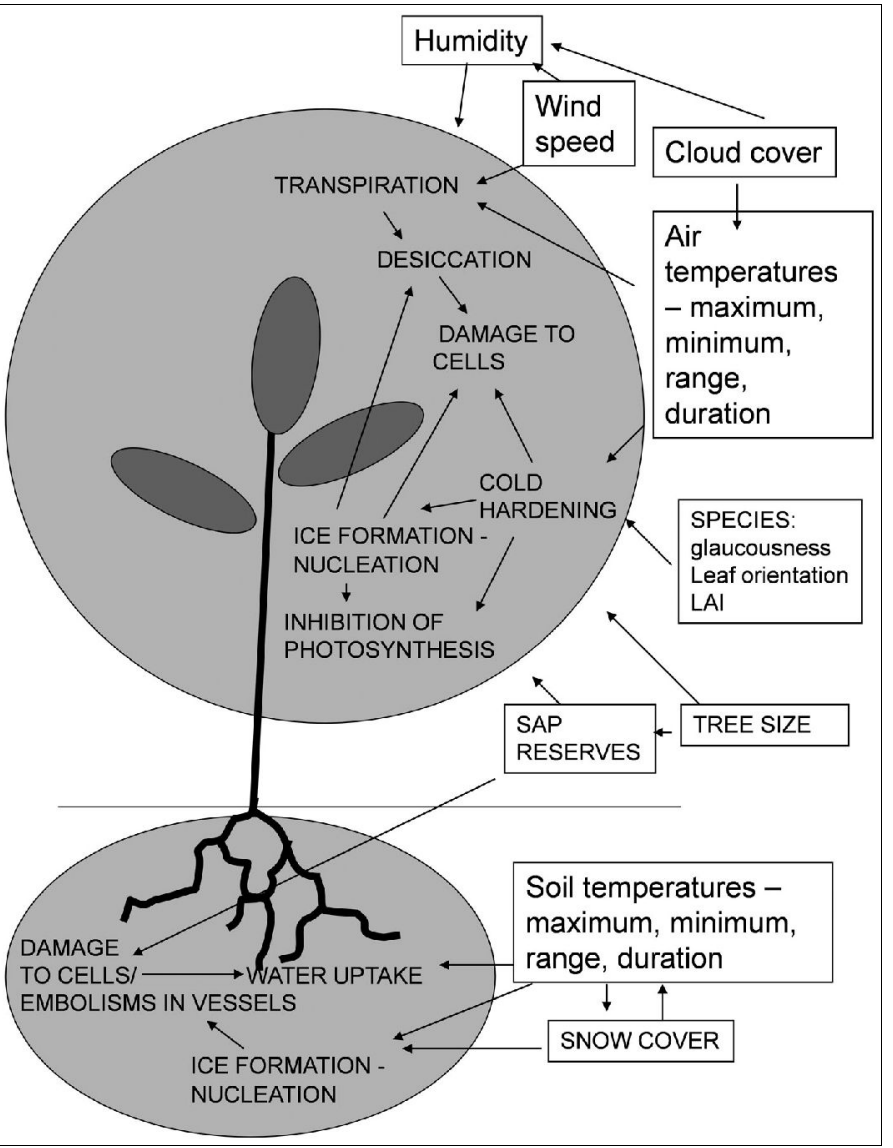

one of the most cold hardy species, being highly resistant even in an unhardened state (Davidson \& Reid 1987). This is supported by results from this trial; by the end of January, $E$. nitens had suffered significantly worse damage then E. gunnii from the cold (Fig. 3 and Fig. 4). However, in early February many of the terminal buds of $E$. nitens still appeared green, flexible and undamaged (Hepburne-Scott. pers. comm.). By May the injury to the trees had increased markedly and only $35 \%$ of the E. gunnii remained alive, while less than $2 \%$ of the $E$. nitens had survived.

Work by Black (unpublished data) in Ireland has shown that there are considerable differences between cold-tolerant eucalypts not only in terms of lethal minimum temperatures but also in their pattern of acclimation to cold. Absolute lethal temperature and ranking by seasonal variance in lethal temperature were combined to produce an overall rank of cold tolerance. Of seven species of eucalypts, E. nitens was found to be the poorest in terms of cold tolerance, with $E$. gunnii being fourth out of the seven species. This contradicts other work that suggests $E$. gunnii is particularly cold-tolerant (Davidson \& Reid 1987).

The evaluation of cold damage to the trees was undertaken using a visual scoring system, but a more reliable and quantifiable ap- proach for evaluating damage to the foliage would have been to measure chlorophyll fluorescence as detailed in Perks et al. (2004). Also, the impacts of cold damage are more often measured under controlled conditions, for example using a freezing cabinet. This is because of the many factors that influence cold damage in the field, such as variation in micro-topography and sky exposure, in the frost hardiness of the trees across and between seasons and between and within populations.

The assessment showed clearly that woody tissues suffered less extensively from damage from the cold than the foliage in both species of eucalypt, an observation supported by others (Scarascia-Mugnozza et al. 1989).

In the assessment of damage carried out in January 2010 there was considerable variation in frost injury between trees, even those adjacent to one another. While some individuals exhibited almost complete damage to foliage, others remained almost uninjured. This variation could be due to differences in: the genetic composition of individuals, the size of the individuals, the micro site they occupied or their treatment during planting and tending. Considerable variation in the frost resistance of provenances and individuals within provenances has been noted in both E. gunnii (Potts 1985, Potts \& Reid 1985a, 1985b) and E. nitens (Tibbits \& Reid
1987, Tibbits \& Hodge 2003, Hamilton \& Potts 2008) in their natural habitats. A study of frost tolerance of 101 origins of E. nitens planted in Tasmania showed the western provenances of the central highlands of Victoria and those from New South Wales to be superior (Tibbits \& Reid 1987), while from early results Evans (1986) found origins of $E$. nitens from Victoria were most cold hardy in trials in Great Britain. For E. gunnii there is convincing evidence from British trials (Evans 1986, Cope et al. 2008) that provenances from Lake MacKenzie are more frost tolerant.

The finding that larger trees are more resistant to damage highlights the importance of obtaining rapid early growth so as to obtain a tree of 1-1.5 m height before the onset of winter. Rapid growth is important, as larger trees have greater sap reserves and once trees reach 2-6 $\mathrm{m}$ the sensitive growing tips are usually above mild growing season radiation frosts (Davidson \& Reid 1987). Furthermore, larger trees exhibit greater physiological maturity and tolerance to environmental stresses than smaller trees of the same age. Ensuring rapid establishment is therefore crucial, including effective weed control and ensuring the trees receive adequate nutrition. Furthermore, good nutrition has also been shown to be important through reducing the extent of photoinhibition in seedlings of $E$. nitens during cold periods (Close \& Beadle 2003). The increase in damage to the very largest trees at the trial may be explained by an imbalance between the root/shoot ratio; many had proven to be unstable being prone to lean and had required additional staking.

The effects of frost can be difficult to predict as both fast recovery and long-term deleterious effects have been noted (Ball 1994, in King \& Ball 1998). The effects of repeated frosts can have a compounding effect on growth and survival, especially in trees in a phase of rapid, early growth, where death of mature leaves and developing shoots can delay investment of resources into new leaves (Ball et al. 1997, in King \& Ball 1998). The weak growth in the summer of 2010 and complete mortality of the E. gunnii that survived the winter of 2009-2010 in the subsequent, milder winter supports this observation. The results from this trial show that following severe cold damage it is best to replant young eucalypts as recovery is unlikely, and even those individuals that have survived are likely to have lower growth and survival.

\section{Conclusions}

The results of this study support the results of others from both field trials (Evans 1986) and laboratory tests (Booth \& Pryor 1991) that E. gunnii is more cold tolerant than $E$. nitens. Only two of the 144 trees assessed of E. nitens survived by May 2010, compared 
with 43 of the 144 trees of E. gunnii. Despite the once in thirty year conditions experienced in winter 2009-2010 and the trees being less than one year on the site, the better survival of E. gunnii suggest in terms of adaptability that it is a species that could be used for producing woody biomass even in northern parts of Britain. Also, it is probable that survival of E. gunnii at the site would have been enhanced by use of material with the origin of Lake Mackenzie, that best adapted to British conditions (Evans 1986, Cope et al. 2008). Relative damage, but not survival is related to the size of the young trees, with larger trees being more resistant. It is therefore imperative that transplants, through intensive silviculture, provision of adequate nutrition, are given the greatest opportunity to establish effectively and grow rapidly before their first winter, when they are particularly vulnerable.

\section{Acknowledgements}

The authors would like to thank the following people: Alastair Chalmers of Pyroclassic Fires for funding half the establishment costs of the trial; Pat Tyers, Graham Leslie and Chris Leslie for helping with data collection and also Kevin Black for providing a draft manuscript of his report on cold tolerance studies on eucalypts in Ireland. They also thank Dr. Conor O'Reilly and Dr. Euan Mason for highlighting areas requiring improvement in the original manuscript.

\section{References}

Almeira MH, Chavez MM, Silva JC (1994). Cold acclimation in eucalypt hybrids. Tree Physiology 14: 921-932. - doi: 10.1093/treephys/14.7-8-9.92 1

Beadle CL, Honeysett JL, Turnbull CRA, White DA (1995). Site limits to achieving genetic potential. Eucalypt plantations: Improving Fibre yield and quality. Theme 5, Ensuring sustainable production, CRC for Temperate Hardwood Forestry. IUFRO, Hobart, Tasmania, pp. 325 330.

Booth T, Pryor L (1991). Climatic requirements of some commercially important eucalypt species. Forest Ecology and Management 43: 47-60. doi: 10.1016/0378-1127(91)90075-7

Boyce RL, Lucero SA (1994). Role of roots in winter water relations of Engelmann spruce saplings. Tree Physiology 19: 893-898. - doi: 10.1093/treephys/19.13.893

Centre for Ecology and Hydrology (2013). Soil data sheet for the Newton Rigg trial. Internal report, CEH - Centre for Ecology and Hydrology, Penicuik, Midlothian, UK, pp. 1.

Close DC, Beadle CL (2003). The ecophysiology of foliar anthocyanin. The Botanical Review 69 (2): 149-161. - doi: 10.1663/0006-8101(2003) 069[0149:TEOFA]2.0.CO;2

Close DC, Beadle CL, Battaglia M (2004). Foliar anthocyanin accumulation may be a useful indi- cator of hardiness in eucalypt seedlings. Forest Ecology and Management 198: 169-181. - doi: 10.1016/j.foreco.2004.03.039

Cochrane PM, Slayter RO (1988). Water relations of Eucalyptus pauciflora near the alpine tree line in winter. Tree Physiology 4: 45-52. - doi: 10.1093/treephys/4.1.45

Commonwealth Government of Australia (1999). Comprehensive Regional Assessment, World Heritage Sub-theme: Eucalypt-dominated vegetation. Report of the Expert Workshop, Canberra (Australia) 8-9 March 1999. [online] URL: http://www.daff.gov.au/_data/assets/pdf_file/00 20/59222/nat_cra_whs.pdf

Cope M, Leslie AD, Weatherall A (2008). The potential suitability of provenances of Eucalyptus gunnii for short rotation forestry in the UK. Quarterly Journal of Forestry 102 (3): 185-194.

Davidson NJ, Battaglia M, Beadle C (1995). Photosynthesis of Eucalyptus nitens is reduced by mild frosts in Eucalypt plantations: improving Fibre yield and quality. CRC for Temperate Hardwood Forestry, IUFRO, Hobart, Tasmania, pp. 339-343.

Davidson NJ, Reid JB (1987). The influence of hardening and waterlogging on the frost resistance of subalpine eucalypts. Australian Journal of Botany 35: 91-101. - doi: 10.1071/BT98700 91

Evans J (1986). A re-assessment of cold-hardy eucalypts in Great Britain. Forestry 59 (2): 223242. - doi: 10.1093/forestry/59.2.223

Hamilton MG, Potts BM (2008). Eucalyptus nitens genetic parameters. New Zealand Journal of Forestry Science 38 (1), p102-119.

Hardcastle PD (2006). A review of the impacts of short-rotation forestry. Final report on SRF, LTS International Inc., Penicuik, Scotland, UK, pp. 168. [online] URL: http://www.forestry.gov.uk/ pdf/SRFFinalreport27Feb.pdf/\$FILE/SRFFinalre port27Feb.pdf

Hovenden MJ, Warren CR (1998). Phytochemistry, energy dissipation and cold hardening in Eucalyptus nitens and E. pauciflora. Australian Journal of Plant Physiology 25: 581-589. - doi: 10.1071/PP98027

Kerr G, Evans J (2011). Eucalypts for short rotation forestry: a case study from the 1980s. Quarterly Journal of Forestry 105 (2): 109-117.

King DA, Ball MC (1998). A model of frost impacts on seasonal photosynthesis of Eucalyptus pauciflora. Australian Journal of Plant Physiology 25: 27-37.

Leslie AD, Mencuccini M, Perks M (2012). The potential for Eucalyptus as a wood fuel in the UK. Applied Energy 89 (1): 176-182. - doi: 10.1016/j.apenergy.2011.07.037

Met Office (2010). Coldest UK winter for over 30 years, 1 March 2010. Web site. [online] URL: http://www.metoffice.gov.uk/corporate/pressoffi ce/2010/pr20100301.html

Met Office (2011a). Winter 2009/10. Web site. [online] URL: http://www.metoffice.gov.uk/climate/uk/2010/winter.html

Met Office (2011b). Summer 2009. Web Site [on- line] URL: http://www.metoffice.gov.uk/climate/ uk/2009/summer.html

Paton DM (1983). Physiology of frost resistance in Eucalyptus. In: "Collogue International sur les eucalypts au froid". Nangis (France) 26-30 September 1983. AFOCEL, Nangis, France, pp. 107-125.

Pearce RS (2001). Plant freezing and damage, botanical briefing. Annals of Botany 87: 417 424. - doi: 10.1006/anbo.2000.1352

Perks MP, Osborne BA, Mitchell DT (2004). Rapid predictions of cold-tolerance in Douglas-fir seedlings using chlorophyll fluorescence after freezing. New Forests 28: 49-62. - doi: 10.1023/ B:NEFO.0000031331.08847.49

Potts BM (1985). Variation in the Eucalyptus gunnii-archeri complex. III. Reciprocal transplant trials. Australian Journal of Botany 33: 687-704. - doi: 10.1071/BT9850687

Potts BM, Reid JB (1985a). Variation in the Eucalyptus gunnii-archeri complex. I. Variation in the adult phenotype. Australian Journal of Botany 33: 337-359. - doi: 10.1071/BT9850337

Potts BM, Reid JB (1985b). Variation in the Eucalyptus gunnii-archeri complex. II. The Origin of variation. Australian Journal of Botany 33: 519-541. - doi: 10.1071/BT9850519

Prior J, Kendon M (2011). The UK winter of $2009 / 2010$ compared with severe winters of the last 100 years. Weather 66 (1): 4-10. - doi: 10.1002/wea.735

Pryor LD (1976). The biology of eucalypts. Studies in Biology No. 61, Edward Arnold, London, UK.

Purse JG, Richardson KF (2001). Short rotation single stem tree crops for energy in the UK - an examination with Eucalyptus. Aspects of Applied Biology 65: 1-8. [online] URL: http://cabdirect.org/abstracts/20023067288.html

Read DJ, Freer-Smith PH, Morison JIL, Hanley N, West CC, Snowdon P (2009). Combating climate change - a role for UK forests. An assessment of the potential of the UK's trees and woodlands to mitigate and adapt to climate change. The Stationery Office, Edinburgh, UK.

Scarascia-Mugnozza G, Valentiny R, Kuzminsky E, Giordano E (1989). Freezing mechanisms, acclimation processes and cold injury in Eucalyptus species planted in the Mediterranean Region. Forest Ecology and Management 29: 81-94. doi: 10.1016/0378-1127(89)90057-1

Tibbits WN, Reid JB (1987). Frost resistance in Eucalyptus nitens (Deane and Maiden) Maiden: Genetic and seasonal aspects of variation. Australian Journal of Forest Research 17: 29-47.

Tibbits WN, Hodge GR (2003). Genetic parameters for cold hardiness in Eucalyptus nitens (Deane and Maiden) Maiden. Silvae Genetica 52 (3-4): 89-97.

Valentini R, Scarascia Mugnozza G, Giordano E, Kuzminsky E (1990). Influence of cold hardening on water relations of three eucalypt species. Tree Physiology 6: 1-10. - doi: 10.1093/treephys/ 6.1 .1 